\title{
Prevention of Armed Conflict in Europe: Comparing the Role of the EU and the US/NATO
}

\author{
Noah Carl ${ }^{1}$ \\ 28 August 2018
}

${ }^{1}$ Independent researcher, UK: noah carl3742@hotmail.com 


\begin{abstract}
The period of relative peace in Europe since the end of the Second World War has been variously described as the 'Pax Europaea' and the 'Pax Americana'. These descriptions reflect two major theories purporting to account for the relative absence of armed conflict during this period: one emphasising the pacifying impact of the EU, and the other emphasising the pacifying impact of the US/NATO. The present paper attempts to evaluate these theories by comparing the role of the EU and the US/NATO in several domains of armed conflict in Europe. It focuses on the mechanisms through which the two organisations have affected the risk and scale of armed conflict within each domain. Although both the EU and the US/NATO have contributed to the relative peace in Europe since the end of the Second World War, there is at least one domain in which each of the organisations has either exacerbated or failed to prevent armed conflict. Understanding the limitations of the two organisations, as well as their strengths, will be important for bolstering European security as the continent faces new geopolitical challenges.
\end{abstract}

Key words: peace, war, armed conflicts, EU, US, NATO 


\section{Pax Europaea and Pax Americana}

It is a fact that, since the end of the Second World War, no two countries in Central or Western Europe have gone to war with one another, despite numerous armed conflicts in the preceding centuries. Indeed, the observed rate of death from armed conflict has plummeted during this time period (Pinker, 2011, Ch. 5). While some scholars have claimed that seven decades worth of data may not be sufficient to conclude that the underlying risk of armed conflict has actually decreased (Cirillo \& Taleb, 2016a; Clauset, 2018), others have noted that both direct and circumstantial evidence suggests that we really are living in a more peaceful era (Pinker, 2012; Spagat \& Weezel, 2018; see Supporting Information for further discussion). The period of relative peace in Europe since the end of the Second World War has been variously described as the 'Pax Europaea' and the 'Pax Americana' (e.g., Gropas, 2008; Layne, 2012). These descriptions reflect two major theories purporting to account for the relative absence of armed conflict during this period: one emphasising the pacifying impact of the EU, and the other emphasising the pacifying impact of the US/NATO.

According to the 'Pax Europaea' theory, the relative absence of armed conflict in Europe over the past seven decades is primarily attributable to the actions and structures of the EU (Cameron, 2016; European Commission, 2016; but see Bickerton, 2015; Stensrud, 2016). As a matter of fact, The European Coal and Steel Community (ECSC), the precursor to the EU, was founded in 1952 with the explicit aim of preventing furthers wars in Europe. For example, the Schuman Declaration (the document calling for the establishment of the ECSC) opens with the words, "World peace cannot be safeguarded without the making of creative efforts proportionate to the dangers which threaten it". Likewise, in his 1943 speech to the French National Liberation Committee, the EU's most important founding father Jean Monnet stated, "There will be no peace in Europe if the States rebuild themselves on the basis of national sovereignty". And in his famous 1946 speech at the University of Zurich, another of the EU's founding fathers Sir Winston Churchill stated:

[There] is a remedy which, if it were generally and spontaneously adopted, would as if by a miracle transform the whole scene, and would in a few years make all Europe, or the greater part of it, as free and as happy as Switzerland is today. What is this sovereign remedy? It is to re-create the European Family, or as much of it as we can, and provide it with a structure under which it can dwell in peace, in safety and in freedom.

Recall that the EU was awarded the Nobel Peace Prize in 2012 for its putative contribution to "the advancement of peace and reconciliation, democracy and human rights in Europe" (The Nobel Committee, 2012). In its press release, the Nobel Committee stated that "the stabilizing part played by the EU has helped to transform most of Europe from a continent of war to a continent of peace."

According to the 'Pax Americana' theory, the relative absence of armed conflict in Europe over the past seven decades is primarily attributable to the actions and structures of the US/NATO (Yost, 2002; Abulafia et al., 2016; and see Patel, 2017). At the end of the Second World War, the US was in a position of 
unprecedented strength. While the former great powers had been devastated by years of heavy shelling and aerial bombardment, the US had suffered virtually no damage to its domestic infrastructure. It was in this context that Sir Winston Churchill called for a "special relationship" between the British Empire and the United States in order to safeguard the nascent peace. In another famous 1946 speech--this one delivered at Westminster College in Fulton, Missouri--he stated:

The United States stands at this time at the pinnacle of world power. It is a solemn moment for the American Democracy. For with primacy in power is also joined an aweinspiring accountability to the future. If you look around you, you must feel not only the sense of duty done but also you must feel anxiety lest you fall below the level of achievement.

The crucial role that the US was expected to play in securing world peace was also recognised by Richard Von Coudenhove-Kalergi, who in 1943 wrote:

During the third century B.C. the Mediterranean world was divided between five great powers [...] The balance of power led to a series of wars until Rome emerged the queen of the Mediterranean and established an incomparable era of two centuries of peace and progress [...] It may be that America's air power could again assure our world, now much smaller than the Mediterranean at that period, two hundred years of peace.

Note that the military and economic dominance established by the US in the aftermath of the Second World War has been compared to that established by the British Empire in the aftermath of Napoleon's defeat at Waterloo (Layne, 2012). And indeed, commentators often claim that Britain is to America as Ancient Greece was to Ancient Rome (e.g., The Economist, 2010).

Notwithstanding the absence of warfare between former great powers, the period since 1952 in Europe has not been one of uninterrupted peace: Table 1 lists the major armed conflicts that have taken place over the last 67 years. The present paper attempts to evaluate the 'Pax Europaea' and 'Pax Americana' theories by comparing the role of the EU and the US/NATO in several domains of armed conflict in Europe. It focuses on the mechanisms through which the two organisations have affected the risk and scale of armed conflict within each domain. The paper begins by examining three domains in which efforts to preserve peace were highly successful: aggression from the Soviet Union; armed conflicts between EU member states; and civil wars in Iberia, Greece and Eastern Europe. It proceeds to examine five domains in which small- or large-scale fighting has taken place: the Wars in Yugoslavia; the War in Donbass; the Turkish invasion of Cyprus; the Troubles in Northern Ireland; and the insurgency in Macedonia.

\section{Domains in which efforts to preserve peace were successful}




\subsection{Aggression from the Soviet Union}

It often goes unappreciated that the primary threat facing Western Europe in the aftermath of the Second World War was not internal conflict (e.g., another war between France and Germany), but rather invasion by the Soviet Union (Stensrud, 2016; Patel, 2017). Yet thanks to mechanisms put in place by the United States, Europe never saw a direct confrontation between the Western allies and the Eastern Bloc, despite numerous proxy wars taking place in other parts of the world. On 12 March 1947, US President Harry Truman announced his administration's new overarching foreign policy, whose aim was to counteract Soviet geopolitical expansionism. Two key pillars of the Truman Doctrine, as it became known, were kickstarting economic recovery in Western Europe through the Marshall Plan, and deterring Soviet aggression via the formation of NATO. Between 1948 and 1952, the US invested over $\$ 12$ billion (corresponding to $\$ 125$ billion in today's money) in the war-ravaged countries of Western Europe, an effort that eventually earned General George Marshall--the plan's chief advocate--a Nobel Peace Prize (US Department of State, 2018a; Mee, 1984). ${ }^{2}$ On 4 April 1949, together with its allies in Canada and Western Europe, the US founded the North Atlantic Treaty Organisation, a collective defence agreement whose Article $\mathrm{V}$ famously stipulates that all member states must come to the aid of any member state that is attacked.

During the four decades of the Cold War--from the end of World War II in 1945 to the collapse of the Soviet Union in 1991--NATO was the main bulwark against a Soviet invasion of Western Europe (Gordon, 1998; Patel, 2017; Johnston, 2017, Pts. I-II). It is noteworthy that the United States has long been, and continues to be, the preeminent military power within NATO (Yost, 2000; Mattelaer, 2017). As Figure 1 shows, since the late 1950s, US defence spending has consistently outstripped EU defence spending. And in fact, as of 2018, the US accounts for a full 70\% of NATO defence spending, whereas EU countries (excluding the UK) account for a mere 20\% (NATO, 2018). Through what means did NATO successfully deter a Soviet invasion? First and foremost, the US stationed a massive nuclear arsenal in Western Europe (Burr, 2006), thereby signalling to the Soviets that any incursion could be met with a nuclear response, and hence the prospect of mutually assured destruction (Schelling, 1990, Pts. 1 \& 4). Second, the US maintained a large troop presence in Western Europe (mostly in Germany, Italy and the UK), which served as an additional deterrent in case the Soviets called America's bluff and sent tanks across the Iron Curtain anyway. As Figure 2 shows, between 1951 and 1991, the US had at least 250,000 troops deployed in Western Europe.

Of course, it could be argued that--insofar as it promoted co-ordination between the countries of Western Europe as part of the 'transatlantic bargain'--the EU made a modest contribution to deterrence as well. Yet as Sloan $(2016$, Ch. 1) notes:

[America's] allies were not nearly so successful in the security area [...] France had proposed the creation of a European Defence Community (EDC) to organise Europe's

\footnotetext{
2 There is some dispute among economists as to exactly how much impact the Marshall Plan had on the economic recovery in Western Europe, although its effects were undoubtedly positive (De Long \& Eichengreen, 1991; Magid, 2012)
} 
military contribution to the bargain. When that initiative failed in 1954, the arrangements adopted in place of the EDC [...] left the transatlantic bargain highly dependent on US nuclear weapons and a substantial US presence in Europe to give credibility to NATO's defence against the Soviet threat.

Moreover, Patel (2017) points out that the European Communities' (EC) trade policy--which imposed barriers on all third-party states--had the effect of fragmenting Western Europe economically, thereby undermining its capacity to coordinate defence efforts. He argues that, up until at least the mid-1970s, the EC was an object of international politics rather more than it was an actor.

\subsection{Armed conflict between EU member states}

There have been no armed conflicts between EU member states over the past seven decades. It therefore makes sense to consider the mechanisms by which the EU and the US/NATO may have contributed to the absence of such warfare, beginning with the EU itself. First, the organisation has fostered communication and exchange between an incrementally expanding number of member states, which is likely to have increased mutual trust and solidarity among their inhabitants (Haftel, 2012, Ch. 1). A second mechanism by which the EU may have contributed to the absence of warfare between member states is promoting interdependence by enhancing opportunities for trade and investment. Indeed, countries living under common political structures generally have much more to lose, and much less to gain, from going to war with one another (Oneal et al., 2003). A third mechanism by which the EU may have contributed is creating reliable channels for conflict resolution (Oneal et al., 2003 Haftel, 2012, Ch. 1). In the EU's case, such channels would include the Council of Ministers, the European Court of Justice and the European Parliament.

By what mechanisms has the US/NATO contributed to the absence of warfare between EU member states? First, together with its allies the United Kingdom and the Soviet Union, the United States signed the Potsdam Agreement on the 1 August, 1945. Among other things, this agreement sought to prevent another war breaking out in Europe through "the complete disarmament and demilitarization of Germany and the elimination or control of all German industry that could be used for military production" (US Department of State, 2018b). Second, by establishing itself as the undisputed leader of the NATO alliance, the US prevented the former great powers from jostling with one another for primacy, thereby neutralising a major source of potential hostility. American leadership was particularly important in reassuring smaller European states that Germany would pursue its national defence policy within the framework of a multilateral alliance (Yost, 2002). Third and most significantly, insofar as Article V of the North Atlantic Treaty binds all members to a collective defence arrangement, the US-led NATO alliance effectively solved the centuries-old security dilemma that had plagued European states.

One point worth reiterating is that the primary threat facing Western Europe in the aftermath of the Second World War was not internal conflict, but rather invasion by the Soviet Union. And according to balance-of-threat theory, the presence of a heavily armed, expansionist state on the borders of Western Europe would have fostered co-operation between countries within Western Europe via the so-called 
'common enemy' effect (see Walt, 1990; De Jaegher \& Hoyer, 2014). Indeed, both the foundation of the ECSC and the formation of NATO were arguably manifestations of this co-operation. Hence one could plausibly assert that the threat posted by the Soviet Union was itself an important reason for the absence of armed conflicts between Western European countries during the four decades of the Cold War.

\subsection{Civil wars in Greece, Iberia and Eastern Europe}

During the 1930s and 1940s, respectively, Spain and Greece became embroiled in two very bloody civil wars: at least 460,000 people died in Spain, and at least 67,000 died in Greece (Sarkees \& Wayman, 2010). Both of these wars were fought between communists on one side and nationalists on the other, reflecting the deep ideological divisions that had arisen in these countries during the first part of the $20^{\text {th }}$ century. Spain was subsequently ruled by the dictator Francisco Franco until his death in 1975, while Greece was ruled by a military junta from 1967 to 1973. Portugal managed to avoid civil war, but was ruled by the authoritarian Estado Novo regime from 1933 to 1974. Given that non-democratic societies are more likely to descend into civil war than those governed by democratic or hybrid regimes (Piccone, 2017), it would be fair to say that Greece, Spain and Portugal were at some risk of internecine conflict in the 1970s.

One important mechanism by which the EC helped to reduce the risk of such conflict was making EC membership conditional on the implementation of democratic reforms (Thomas, 2006; De Angelis \& Karamouzi, 2016). As Thomas (2006) notes, various non-state actors such as EC parliamentarians, trade unionists and other activists mobilised to block Spain's bid for membership in 1962 on account of their opposition to the country's Falangist regime. This set in motion a process by which the principles of democracy, human rights and the rule of law became constitutionalised within the EC's treaties and accumulated laws, particularly the 1978 Declaration on Democracy (De Angelis \& Karamouzi, 2016). Given the widespread anti-American sentiment in Greece and Spain at the time, the role played by the EC in this context cannot be underestimated (Ludlow, 2017).

After the fall of communism in 1991, the EU again helped to reduce the risk of conflict in the fledgling states of Eastern Europe by making membership conditional on the implementation of democratic reforms (Grabbe, 2006; Schimmelfennig \& Scholtz, 2008). NATO too made a positive contribution to stability in Eastern Europe. It did so not only through conditionality of membership (Schweickert et al., 2011), but also through education and training programs for pro-Western political elites. For example, Epstein (2005) explains how NATO used such programs in Poland to build a civilian consensus in favour of democratic and decentralised control over the country's armed forces.

\section{Domains in which fighting has taken place}

\subsection{The Wars in Yugoslavia}


The Yugoslav Wars took place in the present-day countries of Croatia, Serbia, Bosnia and Kosovo between March 1991 and November 2001. The wars were fought between the four main ethnic groups in the region (Catholic Croats, Orthodox Serbs, Bosnian Muslims, and Muslim Albanians) during the dissolution of Yugoslavia, which had existed as a federation of republics since 1918. Because the geographic distribution of these four ethnic groups did not line up with the territorial boundaries of the four republics (in particular, due to the sizable Serb populations in both Bosnia and Croatia, as well as a sizable Croat population in Bosnia), when Croatia and later Bosnia declared independence from Yugoslavia, long-standing ethnic tensions and concerns over political representation spilled out into sectarian violence. The wars were characterised by intense fighting, indiscriminate shelling of cities, and atrocities such as genocide, mass rape and the forced displacement of people (which came to be known as 'ethnic cleansing').

What role did the EU play in the Yugoslav Wars? While Ginsberg (2001, Ch. 4) asserts that "to condemn the EU is too simplistic", other commentators have blamed the EU not only for failing to halt the bloodshed once it had begun, but also--at least to some extent--for aggravating a situation that was already highly volatile (see the accounts in Cohen, 1993; Woodward, 1995; Cafruny, 1998; Holbrooke, 1998; and Glaurdic, 2011). Indeed, the EU arguably made two critical blunders during the course of the wars. The first was its decision to recognise Croatia as an independent state in 1992 without demanding a 'special status' for the Serb minority living there. This decision came following sustained pressure from Germany, which Britain and France interpreted as a cynical attempt by Germany to uphold its historical alliance with Croatia (Glaurdic, 2011, Ch. 10). As Holbrooke (1998, Ch. 1) notes, the British Foreign Secretary Lord Carrington had actually warned his German counterpart that recognising Croatia would set off a chain reaction culminating in war between Bosnian Muslims and Bosnian Serbs.

The EC's second critical blunder was its inability to establish a unified foreign policy, ideally one that included credible threats of military intervention designed to put a stop to the fighting (Holbrooke, 1998; Cafruny, 1998). Indeed, the Serbian leaders were actually emboldened by the EU's failure to impose any sanctions for their continuous flouting of cease-fire agreements and their numerous violations of the UN’s 'no-fly' zone over Bosnia (Cohen, 1993). As Glaurdic (2011, Ch. 1) argues,

To say that the EC/EU failed the Yugoslav test would be a dramatic understatement [...] Their failures in Yugoslavia were indeed so devastating and so profound that the transformation of the EC/EU into a unified actor capable of any common foreign policy was for years rightly considered to be impossible.

The main reason why the EU proved unable to establish a unified foreign policy in Yugoslavia was that its member states had conflicting preferences over crucial issues like whether to prioritise the territorial integrity of Yugoslavia or the principle of self-determination. As already mentioned, France and Britain initially viewed German diplomatic efforts with suspicion, due to their concern that Germany was attempting to reassert its historical influence in the North West of the region. By the same token, in 1991 Britain vetoed a proposed WEU intervention in Croatia, possibly due to the Conservative government's fear that a successful intervention would set the stage for further European military integration (Glaurdic, 
2011, Ch. 8). And in 1994 Greece voted against NATO airstrikes on Serbia, a nation to which it had strong historical and religious ties, and which had supported its position in the Macedonia naming dispute (Curtis, 1995, Ch. 4).

While the Croatian War of Independence ended of its own accord following the Croatian victory in Operation Storm, it took decisive military action from a US-led NATO coalition to bring an end to two of the other Yugoslav Wars: the Bosnian War in December 1995; and the Kosovo War in June 1999 (Cohen, 1993; Woodward, 1995, Ch. 6; Holbrooke, 1998). In the former case, heavy losses due to strategic bombardment by NATO aircraft (via Operation Deliberate Force) convinced the Serbian leaders to come to the negotiating table. They subsequently signed the Dayton Accords along with the leaders of Croatia and Bosnia, marking an end to the three-year conflict. And again in the latter case, mounting losses due to strategic bombardment by NATO aircraft (via Operation Allied Force) compelled the Serbian leaders to withdraw their forces from Kosovo, which brought the fighting to a close. ${ }^{3}$

\subsection{The War in Donbass}

The War in Donbass broke out in April of 2014. Its proximate cause was the ousting of the pro-Russian president Viktor Yanukovych, following the so-called Euromaidan protests in the Ukrainian capital of Kiev between 18 and 23 February 2014. By 27 February, fresh presidential elections had been announced, a new interim government had been installed, and amendments to the constitution that were overturned by Yanukovych in 2010 had been reinstated. These events triggered fighting in the Eastern Donbass region of the country between pro-Russian separatist forces, who opposed the changes in government, and the Ukrainian military. The fighting escalated in the late spring of 2014 when Russian paramilitaries and other unmarked troops entered Eastern Ukraine to bolster the separatist forces. This "stealth invasion" was reportedly accompanied by artillery barrages of Ukrainian military positions from the Russian side of the border (Kramer \& Gordon, 2014).

What role did the EU and the US/NATO play in the War in Donbass? While some experts have attributed the war wholly to Russian belligerence (e.g., Foreign Affairs, 2014; Wilson, 2015; Grant, 2016), a strong case can be made that both the EU and the US/NATO bear some responsibility as well (see the accounts in Mearsheimer, 2014; Kanet, 2015; Menon \& Rumer, 2015; Chengyi, 2017; and Sauer, 2017). To understand why, it is necessary to chart the events that led up to the Euromaidan protests. In July 2008, the EU and Ukraine began negotiating an 'association agreement', which committed Ukraine to cooperate and gradually converge with the EU, thereby serving as a potential stepping-stone to EU membership. As Mearsheimer (2014) points out, the agreement had not only an economic dimension (e.g., reduction of trade barriers, acceptance of EU regulatory standards), but also a security dimension. Specifically, it sought to "promote gradual convergence on foreign and security matters with the aim of Ukraine's everdeeper involvement in the European security area". Meanwhile, Russia was attempting to entice Ukraine

\footnotetext{
${ }^{3}$ It should be noted that, although both the Bosnian and Kosovo Wars were ended thanks to decisive American interventions, the country had earlier supported a UN arms embargo on Yugoslavia, which may have had a deleterious effect overall, given that nearly all armaments were under Serb control (Holbrooke, 1998, Ch. 1).
} 
into its own Eurasian Economic Union, along with other former Soviet states such as Kazakhstan and Belarus.

The negotiations between the EU and Ukraine were taking place against a backdrop of continuing NATO enlargement, something to which Russia had long since expressed its opposition (Reiter, 2001). Six former Eastern Bloc countries had already become NATO members in 2004 (three of which--Estonia, Latvia and Lithuania--lie right on Russia's border), and Russia was concerned that NATO also had designs on Ukraine. As Mearsheimer (2014) notes, these Russian fears were by no means misplaced given that NATO's 2008 Bucharest Summit Declaration had explicitly stated, in reference to Georgia and Ukraine, "that these countries will become NATO members" (NATO, 2008). Indeed, NATO's encroachment upon Ukraine represented a clear red line for Russia, which had always seen Ukraine as belonging to its own sphere of influence. Two months before the 2008 Bucharest Summit, Russian Foreign Minister Sergey Lavrov actually warned US Ambassador William Burns of Russia's concerns about the situation. Burns subsequently sent a cable to US Secretary of State Condoleezza Rice under the title, 'Nyet means nyet: Russia's NATO enlargement red lines' (Sauer, 2017).

In November of 2013, Yanukovych publicly stated that he would not sign the association agreement with the EU, having received a lucrative counteroffer from Russia (Mearsheimer, 2014). Antigovernment, pro-EU demonstrations erupted in Kiev over the next few days. These demonstrations intensified over the following months, leading to the eventual toppling of Yanukovych's government, but not before more than 100 protesters and 18 police officers had been killed in violent clashes (Shveda \& Park, 2016). The EU gave its backing to the demonstrations in two major ways. First, it provided support through the EU-funded European Endowment for Democracy, a fact which the Chairman of the EED's Executive Committee--MEP Alexander Graf Lambsdorff--gave in evidence to the House of Lords in October 2014 (House of Lords, 2015). ${ }^{4}$ Second, several senior EU officials publicly endorsed the demonstrations. For example, two MEPs responsible for the EU's Eastern Partnership policy, Elmar Brok and Jacek Saryusz-Wolski, issued the following statement on 26 November 2013 (European Parliament, 2013):

\begin{abstract}
We believe that Ukraine has a legitimate right to make its European choice. The door for the Ukrainian people remains open. We express our strongest support to the many thousands of Ukrainians who are gathering at Euromaidan Square in the freezing cold in Kiev and in other cities across Ukraine. These peaceful protestors are voicing their strong opposition to the decision not to sign the EU-Ukraine Association Agreement, a decision that deprives them of their European future.
\end{abstract}

\footnotetext{
4 When asked by Lord Trimble about the EED's activities in Ukraine, Lambsdorff said the following: "To give you a particular example, in Ukraine when there were the demonstrations on the Maidan there were media outlets that needed support quickly in order to be able to operate because of financial restrictions. They could apply very quickly and get a decision within less than a week. There were also civil society groups, blogs, newsletters and radio broadcasting that we supported. There was also support for initiatives that sprang out of the Euromaidan movement" (House of Lords, 2014).
} 
Some observers might see the West's backing for the Euromaidan protests as an entirely legitimate attempt to promote an overwhelmingly popular policy (i.e., the association agreement) that was being denied to the Ukrainian people by a duplicitous and authoritarian government. Yet two facts militate against this interpretation. The first is simply that, although Yanukovych reportedly engaged in corruption on a massive scale while on office, he was democratically elected in 2010 with $49 \%$ of the vote. The second is that, at the time the Euromaidan protests started, public opinion in Ukraine was quite evenly divided on the question of whether to join the European Union or the Eurasian Economic Union (Moshes, 2013). For example, as late as February 2014, a poll by the International Republican Institute found that $41 \%$ of Ukrainians favoured joining the European Union, whereas $36 \%$ favoured joining the Eurasian Economic Union (International Republican Institute, 2014). Note that the preceding evidence does not absolve Russia of any responsibility for the War in Donbass. But it does demonstrate that the EU and the US/NATO bear some of the responsibility too. As Mearsheimer (2014) writes, "For Putin, the illegal overthrow of Ukraine's democratically elected and pro-Russian president--which he rightly labelled a "coup"--was the final straw."

\subsection{Other conflicts}

Since 1952, there have been several other armed conflicts in which the EU and/or the US/NATO have played some kind of role: the Turkish invasion of Cyprus; the Troubles in Northern Ireland; and the insurgency in Macedonia. First, on the advice of Secretary of State Henry Kissinger, the US allowed the Turkish invasion of Cyprus to go ahead unimpeded. In fact, Kissinger reportedly vetoed at least one British attempt to pre-empt the Turkish landing (Hitchens, 2001, Ch. 7). According to Kaplan (2004, Ch. 4), the US ultimately sided with Turkey due to its military potential, strategic location and consistent antiSoviet stance. While the EU has made some attempts to resolve the dispute between the two Cypriot communities, these have not been particularly successful (e.g., Kyris, 2012), and as of the present day, the EU still considers Northern Cyprus to be under illegal occupation (Wrange, 2015).

Second, the US encouraged dialogue between the opposing parties in Northern Ireland, which helped to bring an end to The Troubles. It did so through a combination of adroit diplomacy on the part of US President Bill Clinton and the effective application of soft power (Dempsey, 1999; King, 2000; Tonge, 2006, Ch. 1; Cochrane, 2007). The EU has also made a positive contribution to peace in Northern Ireland by facilitating cross-border co-operation and providing structural funds (King, 2000; Tonge, 2006, Ch. 1).

Finally, in the case of the 2001 insurgency in Macedonia, both the EU and NATO played an active role in the resolution of the conflict (Daskalovski, 2004). As a matter of fact, the conflict might have escalated into a full-blown war had it not been for their coordinated intervention. The EU began by urging restraint, while at the same time expressing solidarity with the Macedonian government. It pledged a $€ 40$ million aid package, and by 5 April the two parties had concluded a Stabilization and Association Agreement. Later on 25 June, the EU warned Macedonia that further economic assistance depended on a political settlement being reached. NATO resisted calls for military intervention, and instead pushed for a 
political settlement along with the EU. In addition, it offered to supervise the demilitarisation of the rebels on the condition that leaders of the opposing factions would sign a peace agreement.

\section{Discussion}

The period of relative peace in Europe since the end of the Second World War has been variously described as the 'Pax Europaea' and the 'Pax Americana' (Gropas, 2008; Layne, 2012). These descriptions reflect two major theories purporting to account for the relative absence of armed conflict during this period: one emphasising the pacifying impact of the EU, and the other emphasising the pacifying impact of the US/NATO. The present paper has attempted to evaluate these two theories by comparing the role of the EU and the US/NATO in eight domains of armed conflict in Europe: three in which efforts to preserve peace were successful, and five in which fighting has taken place. It has focused on the mechanisms through which the two organisations have affected the risk and scale of armed conflict within each domain.

Table 2 summarises the impact of the EU and the US/NATO on major armed conflicts in Europe between 1952 and 2019. As can be seen, each institution has had a pacifying impact in some domains, as well as an aggravating impact in one or more other domains. Of the domains in which warfare did not occur (corresponding to the first three rows), arguably the most important one--in terms of both objective risk and potential number of casualties--is aggression from the Soviet Union. The US/NATO had a major positive impact in this domain, whereas the impact of the EU was mixed. Of the domains in which warfare did occur (corresponding to the last five rows), by far the most important one--in terms of total number of casualties--is the Yugoslav Wars. The US/NATO again had a major positive impact in this domain, whereas the EU had a negative impact. Hence it would be fair to say that, although both institutions have contributed to the relative peace in Europe since the end of the Second World War, the US/NATO has made a more significant contribution than the EU.

The US/NATO pre-empted a Soviet invasion of Europe through four key mechanisms: promoting economic growth in Western Europe via the Marshall Plan, achieving collecting defence via NATO Article $\mathrm{V}$, and enhancing deterrence by means of a large troop presence and the prospect of mutually assured destruction. It has contributed to the absence of warfare between EU member states through three key mechanisms: demilitarising Germany and transferring occupied territories after the Potsdam conference; preventing competition among former great powers by asserting military leadership; and obviating the security dilemma via NATO Article V. When European powers were unable to find a diplomatic solution in Yugoslavia, the US/NATO used its overwhelming military strength to bring the Serbs to the negotiating table.

The EU may have contributed to the absence of warfare between its member states through mechanisms such as fostering communication and exchange; enhancing interdependence via trade and investment; and setting up channels for conflict resolution. More importantly, it has used other means at its disposal to enhance stability in potentially volatile regions of the continent, thereby reducing the risk of destructive civil wars. Specifically, it has employed political conditionality (notably the promise of EU 
membership) in order to promote democratic reforms, and has dispensed aid packages and structural funds as a way of bolstering economic development.

Although both the EU and the US/NATO have contributed to the relative peace in Europe since the end of the Second World War, there is at least one domain in which each of the organisations has either exacerbated or failed to prevent armed conflict. These cases illustrate some basic limitations of the two organisations vis-à-vis minimising threats to European security. The US allowed Turkey to invade Cyprus in 1974 because its primary goal at the time was winning the Cold War, not defending every inch of European territory, and Turkey was judged to be a more important ally in that regard than Cyprus/Greece (Kaplan, 2004). Continuing NATO enlargement into Eastern Europe had the effect of stoking conflict in Ukraine, despite advanced warning from Russia and some foreign policy experts that this would be the result. And while it could be argued that pressing on with enlargement was a simple miscalculation, even before the 2014 crisis some analysts were asking whether NATO was in need of fundamental reform (e.g., New York Times, 2013).

During the 1960s and 1970s, the EU played a mostly passive role in regional security (Patel, 2017). It was the NATO alliance--backed by American land forces, aircraft and nuclear weapons--that successfully deterred a Soviet invasion of Western Europe. As a matter of fact, the EU's Common Security and Defence Policy (CSDP) was not even officially established until the signing of the Maastricht Treaty in 1992. Europe's reliance on NATO--both during the Cold War and today--is a result not only of America's undisputed military leadership, but also of European states' lack of willingness to invest in their armed forces (Gordon, 1998). Furthermore, in the 1990s the EC was unable to halt the carnage in Yugoslavia due to the conflicting preferences of its member states. This lack of agreement stemmed, at least in part, from the divergent historical ties of Europe's former great powers: in the Second World War, Germany had been allied with Croatia, whereas Britain and France had been allied with Serbia.

Although the EU has taken concerted steps towards establishing an integrated European army over the last two decades, there are a number of reasons to believe that its defence capabilities will remain comparatively limited for the foreseeable future (Menon, 2002; Alesina \& Perotti, 2004; Rapnouil et al., 2018). In light of recent geopolitical events that have undermined European regional security (notably Brexit and the US pivot to Asia), shoring-up their defence capabilities will be a crucial task for European states--and the EU itself--going forward (Besch, 2016; Gareis \& Wolf, 2016).

\section{References}

Abulafia, D., Somerton, I., Charmley, J. et al. (2016). [Letter to the editor]. The Telegraph, 17 January, published online.

Alesina, A. \& Perotti, R. (2004). The European Union: A Politically Incorrect View. Journal of Economic Perspectives, 18, 27-48.

Besch, S. (2016). EU defence, Brexit and Trump: The good, the bad and the ugly. Centre for European Reform, December, published online.

Bickerton, C. (2015). Can the EU keep the peace in Europe? Not a chance. University of Cambridge, 28 October, published online.

Burr, W. (2006). How Many and Where Were the Nukes? National Security Archive Electronic Briefing Book No. 197, published online. 
Cafruny, A.W. (1998). The European Union and the war in former Yugoslavia: the failure of collective diplomacy. In Cafruny, A.W. \& Peters, P. (Eds.). The Union and the World: The Political Economy of a Common European Foreign Policy. London, UK: Kluwer Law International.

Cameron, D. (2016). PM speech on the UK's strength and security in the EU: 9 May 2016 (Archived). UK Government, 9 May, published online.

Chengyi, P. (2017). Why the Ukraine Crisis Is the West's Fault: A Historical and Philosophical Perspective. International Critical Thought, 7, 267-278.

Churchill, W. (1946a). Speech given at University of Zurich, Switzerland. CVCE, available online.

Churchill, W. (1946b). Speech given at Westminster College, Fulton Missouri. CVCE, available online.

Cirillo, P. \& Taleb, N. (2016a). On the statistical properties and tail risk of violent conflicts. Physica A: Statistical Mechanics and its Applications, 452, 29-45.

Clauset, A. (2018). Trends and fluctuations in the severity of interstate wars. Science Advances, 4, 1-9.

Cochrane, F. (2007). Irish-America, the End of the IRA's Armed Struggle and the Utility of 'Soft Power'. Journal of Peace Research, 44, 215-231.

Cohen, B. (1993). Why Europe Failed to Halt The Genocide in Bosnia. Washington Report on Middle East Affairs, p. 39, published online.

Curtis, G.E. (1995). Greece: A Country Study. Library of Congress: Federal Research Division.

Daskalovski, Z. (2004). The Macedonia conflict of 2001: Between successful diplomacy, rhetoric and terror. Studies in Post-Communism Occasional Paper no. 7, published online.

De Angelis, E. \& Karamouzi, E. (2016). Enlargement and the Historical Origins of the European Community's Democratic Identity: 1961-1978. Contemporary European History, 25, 439-458.

De Long, J.B. \& Eichengreen, B. (1991). The Marshall Plan: History's Most Successful Structural Adjustment Program. NBER Working Paper, published online.

Dempsey, G.T. (1999). The American role in the Northern Ireland peace process. Irish Political Studies, 14, 104-117.

De Jaegher, K. \& Hoyer, B. (2014). Collective action and the common enemy effect. Defence and Peace Economics, 27, 644-664.

Epstein, R.A. (2004). NATO enlargement and the spread of democracy: evidence and expectations. Security Studies, 14, 63-105.

The Economist. (2010). The view from Rome. The Economist, 21 April, published online.

European Commission. (2016). 70 years of lasting peace in Europe. Youtube, European Commission, 21 September, published online.

European Parliament. (2013). Press Release: Key MEPs warn Ukraine authorities not to use force against pro-Europe protestors. European Parliament, 26 November, published online.

Foreign Affairs. (2014). Who Is at Fault in Ukraine? Foreign Affairs' Brain Trust Weighs In. Foreign Affairs, November 9, published online.

Gareis, S.B. \& Wolf, R. (2016). Home Alone? The US Pivot to Asia and Its Implications for the EU's Common Security and Defence Policy. European Foreign Affairs Review, 21, 133-150.

Ginsberg, R.H. (2001). The European Union in International Politics: Baptism by Fire. Lanham, MD: Rowman \& Littlefield.

Glaurdic, J. (2011). The Hour of Europe. New Haven, CT: Yale University Press.

Gordon, P.H. (1998). Europe's Uncommon Foreign Policy. International Security, 22, 74-100.

Grabbe, H. (2006). The EU's Transformative Power: Europeanization Through Conditionality in Central and Eastern Europe. London, UK: Palgrave MacMillan.

Grant, C. (2016). Is the EU to blame for the crisis in Ukraine? Centre for European Reform, 1 June, published online.

Gropas, R. (2008). Pax Europaea: EU Challenges and Prospects in Eurasia, Africa and the Middle East. Woodrow Wilson International Center for Scholars, published online.

Haftel, Y.Z. (2012). Regional Economic Institutions and Conflict Mitigation: Design, Implementation, and the Promise of Peace. Ann Arbor, MI: University of Michigan Press.

Hitchens, C. (2001). The Trial of Henry Kissinger. London, UK: Verso.

Holbrooke, R. (1998). To End a War. New York City, NY: Random House.

House of Lords. (2014). Corrected transcript of evidence taken before The Select Committee on the European Union, Sub-Committee C (External Affairs), Inquiry on The EU and Russia. UK Parliament, published online.

House of Lords. (2015). The EU and Russia: before and beyond the crisis in Ukraine. European Union Committee, 6th Report of Session 2014-15, published online.

International Republican Institute. (2014). Public Opinion Survey Residents of Ukraine, March 14 - 26, 2014. International Republican Institute, published online. 
Johnston, S.A. (2017). How NATO adapts: Strategy and organisation in the Atlantic Alliance since 1950. Baltimore, MY: Johns Hopkins University Press.

Kane, T. (2004). Global U.S. Troop Deployment, 1950-2003. Heritage Foundation, October 27, published online.

Kanet, R.E. (2015). The failed Western challenge to Russia's revival in Eurasia? International Politics, 52, 503-522.

Kaplan, L.S. (2004). NATO Divided, NATO United. Santa Barbra, CA: Praeger.

King, K. (2000). The role of international mediation in the Northern Ireland peace process. In Greenberg, M.C., Barton, J.H. \& McGuiness, M.E. (Eds.). Words Over War: Mediation and Arbitration to Prevent Deadly Conflict. Lanham, MY: Rowman \& Littlefield.

Kramer, A.E. \& Gordon, M.R. (2014). Ukraine Reports Russian Invasion on a New Front. New York Times, 27 August, published online.

Kyris, G. (2012). The European Union and the Cyprus problem: a story of limited impetus. Eastern Journal of European Studies, 3, 87-99.

Layne, C. (2012). The End of Pax Americana: How Western Decline Became Inevitable. The Atlantic, 26 April, published online.

Ludlow, N.P. (2017). More than just a Single Market: European integration, peace and security in the 1980s. The British Journal of Politics and International Relations, 19, 48-62.

Magid, J. (2012). The Marshall Plan. Advances in Historical Studies, 1, 1-7.

Mattelaer, A. (2017). Sharing the burden of keeping Europe whole, free and at peace. NATO Review, 5 May, published online.

Mearsheimer, J.J. (2014). Why the Ukraine Crisis Is the West's Fault. Foreign Affairs, 93, 77-89.

Mee, C.L. (1984). The Marshall Plan: The Launching of the Pax Americana. New York City, NY: Simon \& Schuster.

Menon, A. (2002). Playing with fire: The EU's defence policy. Politique Européenne, 4, 32-45.

Menon, R. \& Rumer, E.B. (2015). Conflict in Ukraine: The Unwinding of the Post-Cold War Order. Cambridge, MA: MIT Press.

Monnet, J. (1943). Speech given to the French Committee for National Liberation in Algiers. CVCE, available online.

Moshes, A. (2013). Will Ukraine Join (and Save) the Eurasian Customs Union? PONARS Eurasia Policy Memo No. 247, published online.

NATO. (2008). Bucharest Summit Declaration. NATO Press Release, 3 April, published online.

NATO. (2018). Defence Expenditure of NATO Countries (2010-2018). NATO Press Release, 10 July, published online.

The Nobel Committee. (2012). The Nobel Peace Prize for 2012. Nobelprize.org, 12 October, published online.

New York Times. (2013). The Opinion Pages, Room for Debate: Has NATO Outlived Its Usefulness? New York Times, 23 April, published online.

Oneal, J.R., Russett, B. \& Berbaum, M.L. (2003). Causes of Peace: Democracy, Interdependence, and International Organizations, 1885-1992. International Studies Quarterly, 47, 371-393.

Patel, K.K. (2017). Who was saving whom? The European Community and the Cold War, 1960s-1970s. The British Journal of Politics and International Relations. The British Journal of Politics and International Relations, 19, 29-47.

Piccone, T. (2017). Democracy and civil war. Brookings Institution Policy Brief, published online.

Pinker, S. (2011). The Better Angels of Our Nature: Why Violence Has Declined. New York City, NY: Viking Books.

Pinker, S. (2012). Fooled by Belligerence: Comments on Nassim Taleb's “The Long Peace is a Statistical Illusion". Published online.

Rapnouil, M.L., Varma, T. \& Witney, N. (2018). Eyes tight shut: European attitudes toward nuclear deterrence. European Council on Foreign Relations, published online.

Reiter, D. (2017). Why NATO enlargement does not spread democracy. International Security, 25, 41-67.

Sauer, T. (2017). The Origins of the Ukraine Crisis and the Need for Collective Security between Russia and the West. Global Policy, 8, 82-91.

Sarkees, M.R. \& Wayman, F. (2010). Resort to War: 1816 - 2007. Washington DC: CQ Press.

Schelling, T.C. (1990). The Strategy of Conflict. Cambridge, MA: Harvard University Press.

Schimmelfennig, F. \& Scholtz, H. (2008). EU Democracy Promotion in the European Neighbourhood: Political Conditionality, Economic Development and Transnational Exchange. European Union Politics, 9, 187-215. 
Schweickert, R., Melnykovska, I. \& Heitmann, H. (2012). Picking Winners? Evidence on NATO's Enlargement Strategy. Transition Studies Review, 18, 570-585.

Shveda, Y. \& Park, J.H. (2016). Ukraine's revolution of dignity: The dynamics of Euromaidan. Journal of Eurasian Studies, 7, 85-91.

Sloan, S.R. (2016). Defence of the West: NATO, the European Union and the Transatlantic Bargain. Manchester, UK: Manchester University Press.

Spagat, M. van Weezel, S. (2018). On the decline of war. UCD Centre for Economic Research, WP18/15.

Stensrud, C. (2016). The EU is not the reason for peace in Europe. Civitas, February, published online.

Stockholm International Peace Research Institute. (2018). Military expenditure by country, in millions of US\$ at current prices and exchange rates, 1949-2016. Stockholm International Peace Research Institute, published online.

Szeptycki, A. (2014). The European Union and the "Euromaidan" in Ukraine. Paper presented at the 8th General Conference of the European Consortium for Political Research, University of Glasgow, 3-6 September, published online.

Thomas, D.C. (2006). Constitutionalization through enlargement: the contested origins of the EU's democratic identity. Journal of European Public Policy, 13, 1190-1210.

Tonge, J. (2006). Northern Ireland (Hotspots in Global Politics). Cambridge, UK: Polity.

US Department of State. (2018a). Marshall Plan, 1948. US Department of State, Office of the Historian, accessed 2018, published online.

US Department of State. (2018b). Foreign relations of the United States: Diplomatic papers, The Conference of Berlin (The Potsdam Conference), 1945, Volume II. US Department of State, Office of the Historian, accessed 2018, published online.

Von Coudenhove-Kalergi, R.N.F. (1943). Crusade for Pan-Europe: Autobiography of a Man and a Movement. New York City, NY: G.P. Putnam's sons.

Walt, S.M. (1990). The Origins of Alliances. Ithaca, NY: Cornell University Press.

Wilson, A. (2015). Ukraine Crisis: What It Means for the West. New Haven, CT: Yale University Press.

Woodward, S. (1995). Balkan Tragedy: Chaos and Dissolution After the Cold War. Washington, DC: Brookings Institution Press.

Wrange, P. (2015). Occupation/annexation of a territory: Respect for international humanitarian law and human rights and consistent EU policy. European Parliament, Directorate-General for External Policies.

Yost, D.S. (2000). The NATO Capabilities Gap and the European Union. Survival, 42, 97-128.

Yost, D.S. (2002). Transatlantic relations and peace in Europe. International Affairs, 78, 277-300. 


\section{Tables and Figures}

Table 1. Major armed conflicts in Europe between 1952 and 2019.

\begin{tabular}{|c|c|c|c|}
\hline Name of conflict & Location & Dates & Number of deaths \\
\hline Cyprus emergency & Cyprus & 1955-1959 & 750 \\
\hline Hungarian revolution & Hungary & 1956 & 3,000 \\
\hline Basque conflict & Spain, France & $1959-2011$ & 1,071 \\
\hline The Troubles & Northern Ireland, Britain, Ireland & $1968-1998$ & 3,532 \\
\hline Soviet invasion of Czechoslovakia & Czechoslovakia & 1968 & 159 \\
\hline Turkish invasion of Cyprus & Cyprus & 1974 & 1,500 \\
\hline Wars in Yugoslavia & Croatia, Serbia, Bosnia, Kosovo & $1991-2001$ & 140,000 \\
\hline Romanian revolution & Romania & 1989 & 1,200 \\
\hline Transnistria War & Transnistria, Moldova & 1992 & 585 \\
\hline Unrest in Albania & Albania & 1997 & 2,000 \\
\hline Insurgency in Macedonia & Macedonia & 2001 & 200 \\
\hline War in Donbass & Ukraine & 2014-2019 & 12,900 \\
\hline
\end{tabular}

Notes: Death counts should be considered approximate. These were compiled from a variety of sources, which are available in the data supplement on the OSF page. Islamist terrorism, far-right terrorism and far-left terrorism were excluded on the grounds of being too sporadic.

Table 2. Summary of the impact of the EU and the US/NATO on major armed conflicts in Europe between 1952 and 2019.

\begin{tabular}{lcc}
\hline \multicolumn{1}{c}{ Domain } & EU & US/NATO \\
\hline Deterring aggression from the Soviet Union & Mixed & Major positive impact \\
Preventing wars between EU member states & Positive impact & Positive impact \\
Preventing civil wars in Iberia, Greece and Eastern Europe & Positive impact & Positive impact \\
Resolving the Turkish invasion of Cyprus & Mixed & Negative impact \\
Resolving the Wars in Yugoslavia & Negative impact & Major positive impact \\
Resolving the Troubles in Northern Ireland & Positive impact & Positive impact \\
Resolving the insurgency in Macedonia & Positive impact & Positive impact \\
Preventing the War in Donbass & Negative impact & Negative impact \\
\hline
\end{tabular}

Notes: See text for references. Islamist terrorism and far-right terrorism were excluded on the grounds of being too sporadic. 
Figure 1. Military expenditure by the US and the EU from 1957 to 2017.

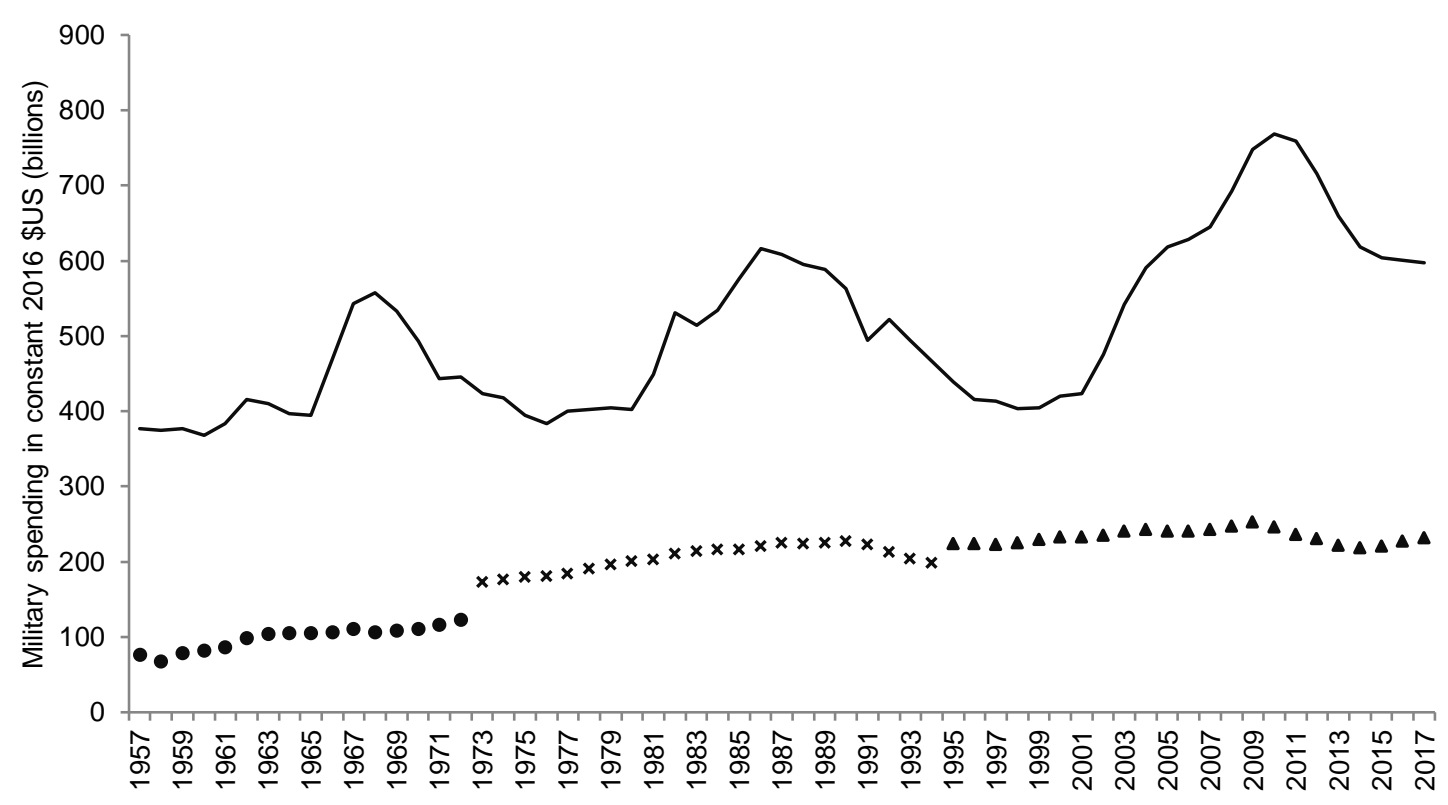

Notes: Data were taken from the Stockholm International Peace Research Institute (2018). Figures for the EU-9 and the EU-15 include the UK.

Figure 2. US troops deployed in Europe from 1950 to 2005.

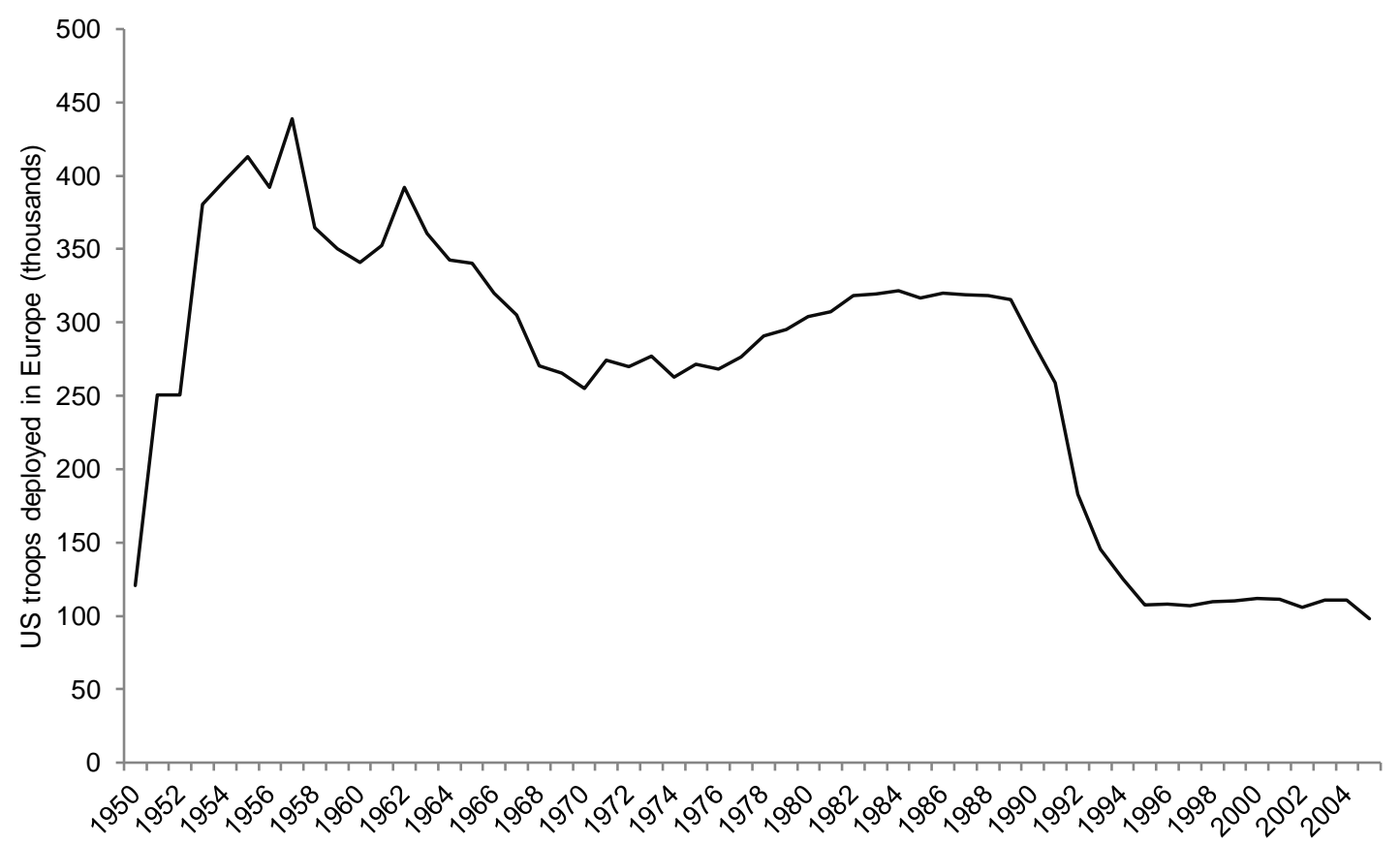

Notes: Data were taken from Kane (2004). 